University of Nebraska - Lincoln

DigitalCommons@University of Nebraska - Lincoln

Faculty Papers and Publications in Animal

Science

Animal Science Department

1972

\title{
A Biopsy Technique for Sampling the Gracilis Muscle in the Baby Pig
}

B. D. Moser

University of Nebraska-Lincoln

E. R. Peo, Jr.

University of Nebraska-Lincoln

D. R. Zimmerman

University of Nebraska-Lincoln

P. J. Cunningham

University of Nebraska-Lincoln

Follow this and additional works at: https://digitalcommons.unl.edu/animalscifacpub

Part of the Animal Sciences Commons

Moser, B. D.; Peo, Jr., E. R.; Zimmerman, D. R.; and Cunningham, P. J., "A Biopsy Technique for Sampling the Gracilis Muscle in the Baby Pig" (1972). Faculty Papers and Publications in Animal Science. 635.

https://digitalcommons.unl.edu/animalscifacpub/635

This Article is brought to you for free and open access by the Animal Science Department at DigitalCommons@University of Nebraska - Lincoln. It has been accepted for inclusion in Faculty Papers and Publications in Animal Science by an authorized administrator of DigitalCommons@University of Nebraska - Lincoln. 


\title{
A BIOPSY TECHNIQUE FOR SAMPLING THE GRACILIS MUSCLE IN THE BABY PIG ${ }^{1}$
}

\author{
B. D. Moser, E. R. Peo, Jr., D. R. Zimmerman and P. J. Cunningham \\ University of Nebraska, Lincoln $68503^{2,3}$
}

$\mathbf{I}^{\mathrm{N}}$ research it is often desirable to measure body composition at different stages of growth. Ideally, if the same animal could be sampled several times during the growingfinishing period, critical information about tissue growth could be obtained. Thus, the development of a simple procedure to obtain tissue samples would be an asset to the researcher.

Tissue growth is estimated usually bv samples obtained from animals slaughtered at various weights. The use of a biopsy technique eliminates the necessity of slaughter of experimental animals to assess changes in muscle tissue. Merkel et al. (1954) and Wilson et al. (1955) working with swine and cattle, respectively, described surgical procedures by which a sample was excised from the intact muscle. Everitt and Carter (1961) and Bray (1963) used an instrument similar to a cork borer to obtain a muscle sample; whereas, Harris and Bennett (1970) used a "muscle tissue extractor" to sample the semitendinosus and longissimus muscles of cattle. The above biopsy techniques were developed with larger, more mature animals, and thus may not be directly applicable to the young pig.

Therefore, the objective of the research reported herein was to develop a rapid, convenient method for serially sampling the gracilis muscle of the live, early-weaned pig without adversely affecting animal performance.

\section{Experimental Procedure}

A biopsy of the gracilis muscle was accomplished with 240 early-weaned pigs whose mean initial and final weights were 4.1 and

\footnotetext{
1 Published with the approval of the Director as Paper No. 3238, Journal Series, Nebr. Agr. Exp. Sta. Research reported was conducted under Project 13-11.

2 Department of Animal Science, Acknowledgement is made to $C$. H. Naber and C, E. Albright for their assistance in the conduction of the biopsy.

3 Mention of commercial products does not imply endorsement at the exclusion of similar products.
}

$15.4 \mathrm{~kg}$, respectively. Two biopsies were performed on each pig, one at the beginning and one at the end of a 35-day trial. The left thigh was randomly selected as the site for the initial biopsy for all pigs. The gracilis muscle in the right thigh was selected for the final biopsy because the initial biopsy removed most of the gracilis muscle in the left thigh since this muscle is relatively small in pigs weighing 4.0 kilograms.

The procedure for obtaining the muscle sample was as follows: the pigs were restrained on their backs in a $\mathrm{V}$-shaped device. The sample area on the medial surface of the thigh was scrubbed thoroughly with a surgical scrub, ${ }^{4}$ disinfected with Ves-phene ${ }^{5}$ and rinsed clean.

The incision area was treated topically with a local anesthetic ${ }^{6}$ which was allowed to remain on the skin for 20 to $25 \mathrm{sec}$. to render the surface insensitive during the incision and extraction of the sample (Harris and Bennett, 1970 , stated that 20 to $25 \mathrm{sec}$. was an adequate time lapse for anesthetization when liquid nitrogen was used as a local anesthetic).

Using a conventional scalpel an incision 2.5 $\mathrm{cm}$ long was made through the skin in approximately the center of the medial surface of the thigh. To reduce bleeding blunt dissection was used to separate the fat and connective tissue covering the muscle. After the fat and connective tissue had been completely penetrated, a group of gracilis muscle bundles was then teased apart and lifted up through the incision with forceps (figure 1). The bundles were loosened by inserting two forceps under the muscle and rotating one over the other. The bundles were then firmly grasped with a pair of hemostats for ease of holding during sectioning. The distal and proximal

\footnotetext{
4 Septisol Vestal Laboratories, Division of W. R. Grace and Company.

$\bar{\sigma}$ Germical Detergent Vesta Laboratories, Division of W. R Grace and Company.

a Xylocaine (Lidocaine Hydrochloride) Astra Pharmaceuticat Products, Inc., Worcester, Mass. 01606.
} 


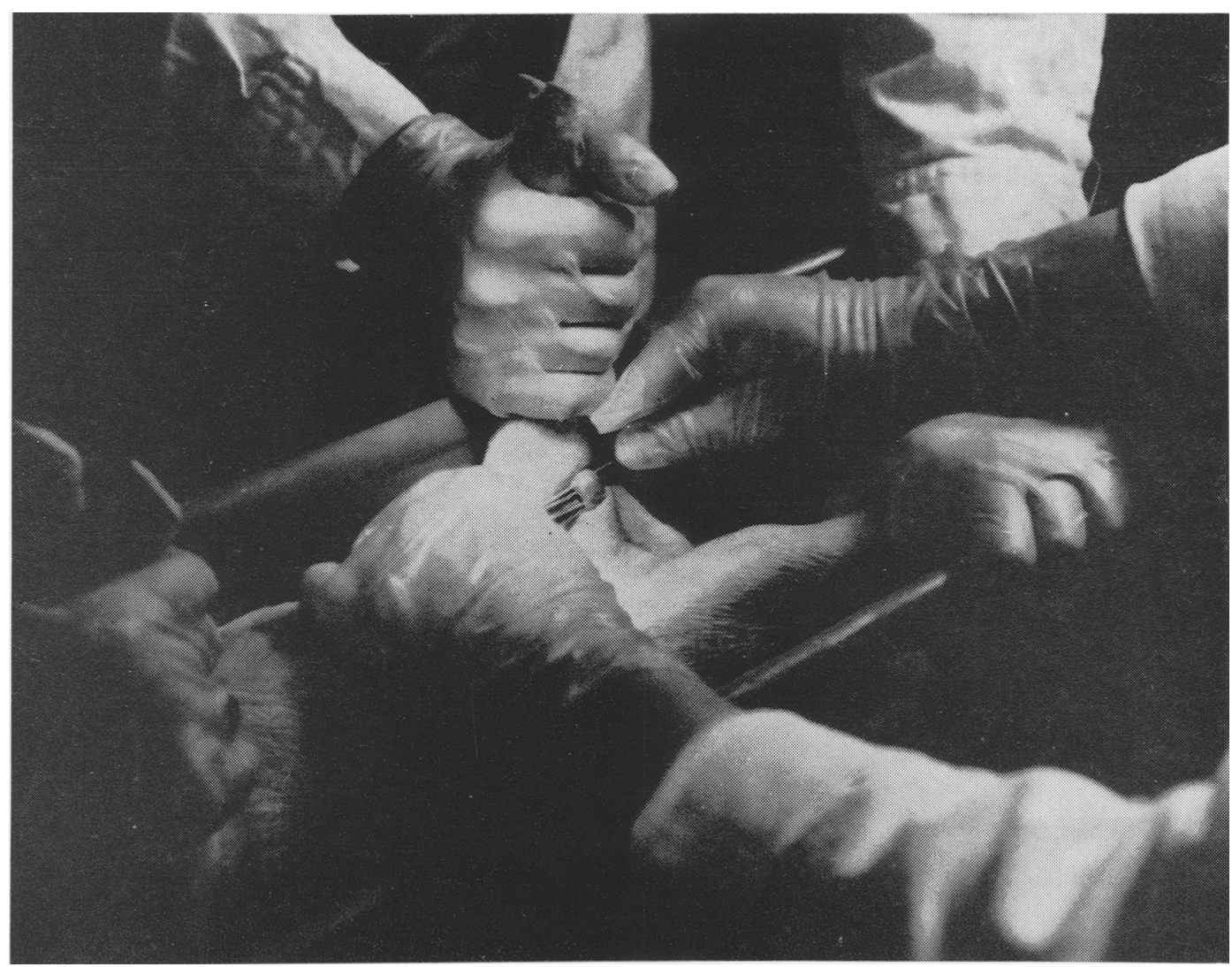

Figure 1. Photograph shows a group of gracilis muscle bundles lifted up through the incision.

ends, respectively, of the sample were then severed from the remainder of the muscle with an electric-cautery knife (figure 2). With this method, the blood vessels were cauterized, thereby preventing or restricting any bleeding which could occur when the cautery knife was moved through the muscle too quickly and cauterization was incomplete or when the muscle bundles were torn apart and not cauterized. After removal, the sample (figure 2) was placed in a plastic container and frozen immediately with dry ice for future analyses. The incision through the skin was closed with two sutures. Absorbable suture with an attached cutting needle was used. The suture sizes for the initial and final biopsies were 00 and 0 , respectively. The wound was dressed with sulfa-urea medication (powder in the incision site; cream after stitches were in place) and each animal was given, intramuscularly, $2 \mathrm{ml}$ of an injectable procaine penicillin-streptomycin mixture. After the biopsy was complete the pigs were returned to their experimental pens. The experimental pens were equipped with automatic waterers, self-feeders and supplemental radiant heat lamps. The pens were not bedded and were $1 / 3$ slotted floored.

The gracilis muscle is a wide, quadrilateral muscle which is situated behind the sartorius, and covers the greater part of the medial surface of the thigh. This muscle was chosen for the following reasons: (1) the location is such that once the pig is restrained on his back the biopsy can be completed rather easily. Also, the biopsy site, being on the inside of the thigh should be somewhat protected from gross contamination by foreign material; (2) according to Sisson and Grossman (1948) the only function of the gracilis is to adduct the limb. Since other muscles, such as the semimembranosus, sartorius and adductor perform 

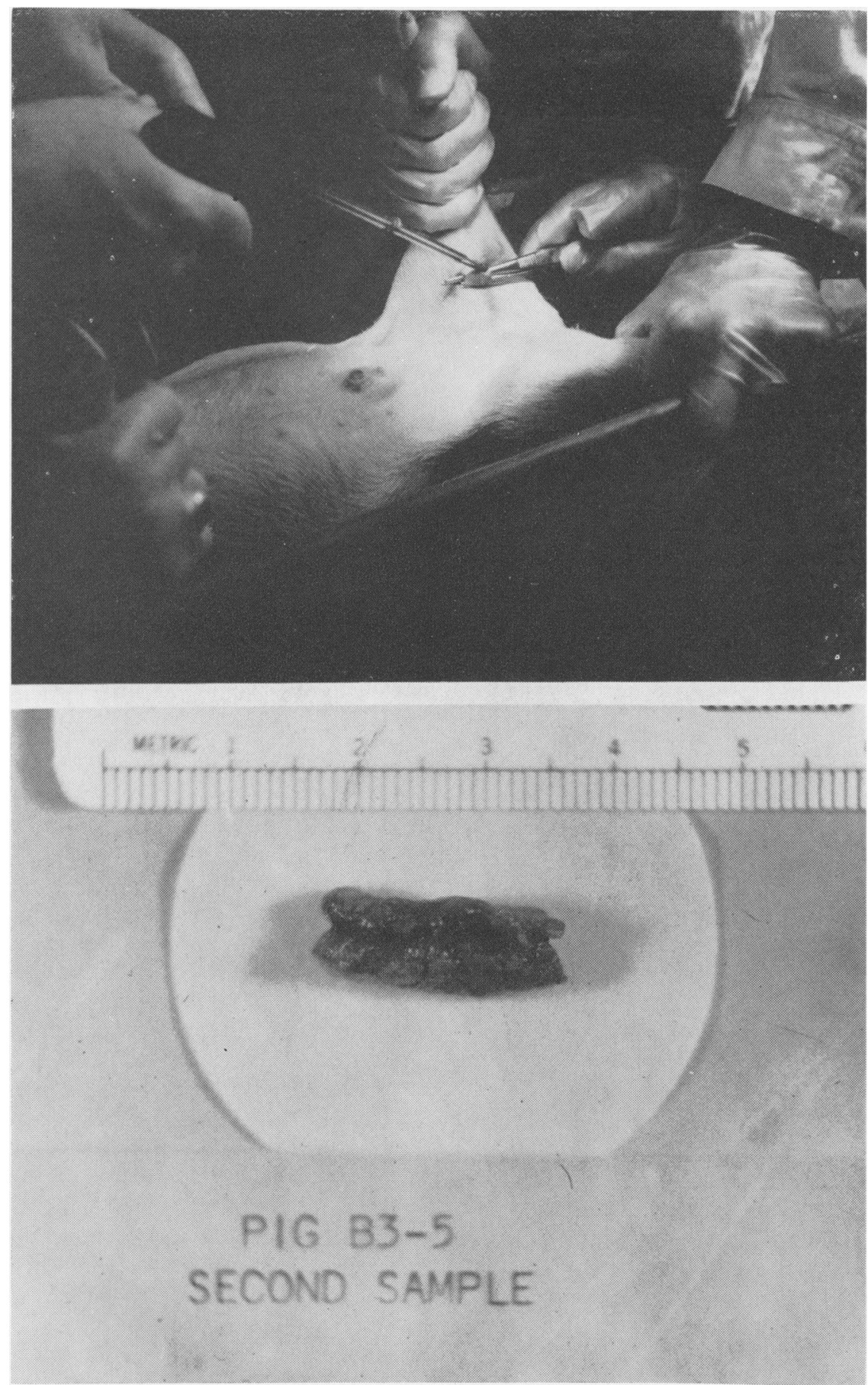

Figure 2. Upper photograph: The sample is excised with an electric-cautery knife.

Lower photograph shows the approximate size of sample taken from the gracilis muscle. 
similar functions, removal of a portion of the gracilis should not appreciably affect mobility of the pig; (3) the muscle fibers run parallel with the limb which aids in the process of teasing out the muscle bundles and (4) the gracilis muscle varies in size proportional to other muscles of the ham, as indicated by the swine conformation cross-sectional slides of pigs of various degrees of muscling prepared by Kline and Christian (1968).

\section{Results and Discussion}

A biopsy of the gracilis muscle was successfully accomplished on 240 early-weaned pigs. An experienced technician performing the necessary surgical procedures and aided by three assistants to restrain the pig and cleanse the surgical area can obtain a sample of the gracilis muscle of a baby pig in approximately 7 minutes. Samples were taken from both the left and right thighs with no apparent adverse effect upon the animal. The mean initial and final sample weights were 0.60 and $1.00 \mathrm{~g}$, respectively. The overall average daily gain and feed conversion (gain/feed) for the 35day period following the initial biopsy were $0.32 \mathrm{~kg}$ and 0.51 , respectively, for pigs fed diets containing various levels and sources of protein.

The initial sample weight appears to be sufficient for most analytical determinations. For example, the initial $0.60 \mathrm{~g}$ muscle sample was adequate for analysis for RNA and DNA as outlined by Schneider (1945).

Most of the animals suffered no visible postoperative reaction to the biopsy. Merkel et al. (1954) stated that hemorrhage resulting from resection of the muscle was controlled by gauze tampons, and occasionally it was necessary to ligate larger vessels to arrest bleeding. As indicated earlier the use of the electric-cautery knife and the biopsy procedure outlined herein resulted in little bleeding, and little trauma to the surrounding tissue. What little swelling did occur receded within a week. Fluid occasionally accumulating at the biopsy site was removed easily by use of a 16 gauge hypodermic needle. The incidence was extremely low ( 6 of 480). This fluid accumulation appeared to have no effect on the performance of the pigs in which it occurred.
Also, an occasional minor infection occurred at the biopsy site. Again, the incidence was low (4 of 480) and pigs with the infection were treated with an injectable procaine penicillin-streptomycin mixture. Harris and Bennett (1970), using a surgical biopsy technique, also observed only rare infections when longissimus and semitendinosus muscles were sampled. They stated that a topical disinfectant spray on the wound following the biopsy was adequate protection. At the end of the present 35-day trials the wounds had healed completely and it was difficult to identify the location of the incisions.

Since animal performance was not adversely affected, serial biopsy of the gracilis muscle provides a tool for researchers interested in the effects of nutrition or other factors on muscle composition.

\section{Summary}

A biopsy of the gracilis muscle was successfully accomplished on 240 early-weaned pigs whose mean initial and 35-day weights were 4.1 and $15.4 \mathrm{~kg}$, respectively. The procedure for obtaining the muscle sample was as follows: The pig was restrained on its back in a V-shaped device. The sample area on the inside of the thigh was cleansed thoroughly, disinfected and treated topically with a local anesthetic. An incision $2.5 \mathrm{~cm}$ long was made through the skin. Blunt dissection was used to separate the fat and connective tissue covering the muscle. A sample was cut from the rest of the muscle with an electric-cautery knife. After removal from the animal, the sample was placed in a plastic container and frozen immediately with dry ice for later analyses. The incision was closed with two sutures, sulfa-urea medication applied to the wound and the animal was given $2 \mathrm{ml}$ of an injectable procaine penicillin-streptomycin mixture. The time required to collect the sample was approximately $7 \mathrm{~min}$. per pig. The mean weights of the initial and 35-day muscle samples were $0.60 \mathrm{~g}$ and $1.00 \mathrm{~g}$, respectively. Average daily gain $(\mathrm{kg})$ and gain/feed for the 35-day period following the initial biopsy were 0.32 and 0.51 , respectively. Since animal performance was not adversely affected, serial biopsy of the gracilis muscle provides a tool 
for researchers interested in the effects of nutrition and other factors on muscle composition.

\section{Literature Cited}

Bray, R. W. 1963. Biopsy and core techniques for estimating composition. Ann. N.Y. Acad. Sci. 110: 302.

Everitt, G. C. and A. H. Carter. 1961. Growth and muscle development of steers, implanted with hexoestrol. J. Agr. Sci. 57:213.

Harris, R. M. and James A. Bennett. 1970. Mechanism for biopsy sampling. J. Anim. Sci. 31:451.

Kline, E. A, and L. L. Christian. 1968. Swine con- formation, a cross-section view. Iowa State University, Ames.

Merkel, K. A., D. K. Sorensen, T. Kowalczyk and R. W. Bray. 1954. Technique for securing tissue to study muscular fat deposition in swine. Cornell Vet. $44: 3$

Schneider, W. C. 1945. Phosphorus compounds in animal tissues, I. Extraction and estimation of desoxy pentose nucleic acid and of pentose nucleic acid. J. Biol. Chem. 161:293.

Sisson, S. and J. D. Grossman. 1948. The Anatomy of the Domestic Animals. W. B. Saunders Company, Philadelphia and London. p. 327.

Wilson, G. D., W. E. Batterman, D. K. Sorensen, T. Kowalczyk and R. W. Bray. 1955. A biopsy technique and its use in studying changes in muscle during fattening. J. Anim. Sci. 14:398. 